\title{
Seroprevalensi Sistiserkosis pada Babi di Wilayah Wamena, Papua
} (SWINE CYSTICERCOSIS SEROPREVALENCE IN WAMENA, PAPUA REGION)

\section{Alvionita Lingga*, Ida Bagus Ngurah Swacita, I Ketut Suada}

\author{
Laboratorium Kesehatan Masyarakat Veteriner, Fakultas Kedokteran Hewan, Universitas
} Udayana. Jl. PB. Sudirman Denpasar, Bali.*Email: alvionitalingga.al@gmail.com

\begin{abstract}
ABSTRAK
Sistiserksosis merupakan penyakit zoonosis disebabkan oleh larva cacing Taenia solium yang berdampak serius pada kesehatan hewan maupun manusia. Papua merupakan salah satu daerah endemis sistiserkosis di Indonesia. Penelitian ini bertujuan untuk mengetahui seroprevalensi sistiserkosis pada babi di wilayah Wamena, Papua. Sebanyak seratus sebelas sampel serum babi yang disampling dari wilayah Wamena kemudian diuji dengan Enzyme Linked Immunosorbent Assay (ELISA). Hasil penelitian menunjukkan bahwa seroprevalensi sistiserkosis pada sampel babi tersebut sebanyak 39,64\% (44/111). Dapat disimpulkan bahwa seroprevalensi sistiserkosis pada sampel babi dari Wilayah Wamena, Papua sangat tinggi, dengan demikian maka diperlukan program untuk memberantas penyakit ini oleh instansi terkait di Wilayah Wamena, Papua.
\end{abstract}

Kata kunci: Seroprevalensi; sistiserkosis; babi; Wamena; Papua.

\section{ABSTRACT}

Cysticercosis is a zoonotic disease caused by the larvae of Taenia solium which can affect human and animal health. Papua is one of the endemic areas of cysticercosis in Indonesia. This study aim was to determine the seroprevalence of swine cysticercosis in the region of Wamena, Papua. A total of a hundred and eleven swine serum samples collected from the region was then tested by using Enzyme Linked Immunosorbent Assay (ELISA). The results showed that the seroprevalence of cysticercosis in swine samples was $39.64 \%$ (44/111). It can be concluded that the seroprevalence of cysticercosis in swine of the region Wamena, Papua is realtively high. Therefore, it needs to design the disease control and eradicate program by relevant agencies in the region of Wamena, Papua.

Keywords: Seroprevalence; cysticercosis; swine; Wamena; Papua

\section{PENDAHULUAN}

Babi merupakan salah satu hewan ternak yang sejak dahulu sangat disenangi masyarakat karena banyak manfaatnya dalam kehidupan maupun kesejahteraan manusia. Pemeliharaan babi juga tergolong tidak terlalu susah dikarenakan hewan ini termasuk omnifora, yaitu hewan pemakan segala jenis pakan, baik yang berasal dari tumbuhan maupun dari binatang (Ardana dan Putra, 2008; Agustina et al., 2016).

Wamena adalah sebuah distrik di Kabupaten Jayawijaya, Provinsi Papua, sekaligus merupakan ibu kota kabupaten tersebut. Kabupaten Jayawijaya dibentuk berdasarkan Undang-Undang Nomor 12 Tahun 1969, tentang pembentukan Provinsi
Otonom Irian Barat dan KabupatenKabupaten Otonom di Provinsi Irian Barat.

Babi merupakan ternak penting bagi masyarakat Wamena, bahkan nama kota Wamena diambil dari nama Babi yaitu Wam dan Ena: Wam artinya babi dan Ena artinya jinak, jadi Wamena berarti Babi jinak. Babi jinak terkenal di Wamena, yang mana dalam budaya lokal, masyarakat sering mengambil anak babi lalu dipelihara secara intensif seperti halnya orang memelihara anjing, sehingga Wamena atau babi jinak ini menjadi babi yang sangat akrab dan manja dengan manusia, bahkan ibu-ibu sering memberikan ASI mereka pada anak babi jinak.

Babi merupakan hewan yang mempunyai kedudukan penting bagi masyarakat pedalaman daerah Wamena, 
masyarakat di pedalaman mempunyai kebiasaan memelihara babi tanpa dikandangkan, sehingga ternak tersebut bebas berkeliaran. Babi yang berkeliaran tersebut sering juga memakan tinja manusia. Hal ini dikarenakan, masyarakat sering melakukan defikasi di sembarang tempat, terutama di ladang atau kebun sekitarnya (Agustina et al., 2017). Jika tinja manusia tersebut mengandung telur cacing pita atau Taenia solium, maka secara otomatis babi tersebut telah mengkonsumsi telur cacing Taenia solium sehingga dalam tubuhnya akan mempunyai kista atau sistiserkus. Sistem defikasi yang tidak saniter ini akan menjadi media pencemar bagi tanah, air dan tanaman sekitarnya.

Sistem sanitasi umum dan higiene perorangan di daerah inipun sangat buruk. Menurut Laporan Tahunan Dinas Kesehatan Provinsi Papua (2006), Kabupaten Jayawijaya merupakan salah satu daerah yang memiliki status kesehatan lingkungan (sanitasi) terendah di Propinsi Papua. Sebagian besar $(98.0 \%)$ penduduk Kabupaten Jayawijaya tidak memiliki fasilitas/sarana sanitasi seperti air bersih, jamban keluarga, tempat pembuangan sampah dan saluran pembuangan air limbah (SPAL) (Maitindom, 2008).

Sistiserkosis merupakan kista cacing pita pada babi yang terinfeksi Taenia solium. Sistisercosis pada babi yang terinfeksi biasanya sering ditemukan pada otot-otot lidah, diafragma, intercostae, hati dan otot gerak lainnya, daging dan jeroan babi lainnya. Namun, bagi masyarakat Wamena mengkonsumsi babi merupakan hal yang umum dan identik dengan istilah bakar batu. Bakar batu menjadi ciri khas masyarakat Papua memasak daging babi dengan batu panas yang dibakar sebelumnya. Bakar batu adalah salah satu acara adat terpenting sebagai wujud kegembiraan menyambut kelahiran, kematian anggota keluarag atau untuk mengumpulkan prajurit dalam berperang. Bakar batu juga menjadi sarana pemulihan ketidakharmonisan hidup manusia, peperangan dan upacara kematian. Namun, babi yang dimasak dengan bakar batu biasanya tidak masak sempurna atau setengah matang (Wandra et al., 2007b). Hal ini diyakini juga menjadi faktor yang mempengaruhi tingginya kasus sistiserkosis di daerah itu. Di Wamena, penelitian sistiserkosis pada babi yang dilakukan tahun 1998-1999 menunjukkan prevalensi sebesar 70,4\%, sedangkann untuk Kabupaten Jayawijaya secara keselurahan tingkat prevalensi sistiserkosis mencapai 77,1\% (Margono et al., 2003).

Selama ini, penelitian tentang sistiserkosis/taeniosis di wilayah ini sebagian besar dilakukan pada manusia (Assa, 2012). Menurut laporan Dinas Kesehatan Provinsi Papua (2004) dari 356 orang penduduk Kabupaten Jayawijaya yang diperiksa, 4 orang menderita taeniasis dan 124 orang sistiserkosis. Pada tahun 2005 dilaporkan, bahwa dari 38 orang yang diperiksa 12 orang ditemukan terinfeksi taeniasis (Dinkes Papua 2005). Di sisi lain studi tentang peran babi dalam transmisi penyakit ini belum pernah dilakukan. Selama ini belum pernah ada catatan dan laporan secara sistematik di Dinas Peternakan Provinsi Papua tentang kejadian sistiserkosis yang terjadi setiap tahun pada babi di Kabupaten Jayawijaya (Maitindom, 2008). Dalam penelitian ini dilakukan kerja sama dengan Dinas Peternakan Papua, dimana sampel serum babi di wilayah Wamena diuji terhadap infeksi sistiserkosis dan dihitung tingkat seroprevalensinya.

\section{METODE PENELITIAN}

Penelitian ini menggunakan 111 sampel serum babi yang dikirim oleh Dinas Peternakan Provinsi Papua yaitu dari wilayah Wamena, Papua. Bahan yang digunakan dalam penelitian ini berupa sampel serum babi yang diuji menggunakan Enzym Linked Immunosorbent Assay (ELISA) terhadap antibodi larva $T$. solium sebagai sumber antigen yang diperoleh dari Wamena, Papua, kits komersial antara lain konjugat goat anti swine IgG HRP (Horse Radish Peroksidase), Substrat TMB 
(Tertramethylbenzidine), stopper (asam sulfat), PBS (Phosphate Buffer Saline) Tween 20 (PBS-T), dan skim milk. Peralatan yang digunakan dalam penelitian ini adalah stiker kertas, tabung sentrifuse dan sentrifugator, transferpette, mortar, spuit, Q-Fluorometer, tabung eppendorf, pipet mikro tips, mikro drpos, platmikro ELISA, ELISA reader dan tabung falcon.

Antibodi sistiserkus dideteksi menggunakan metode ELISA indirect (tidak langsung). Untuk mendeteksi antibodi terhadap C. cellulosae pada serum babi, digunakan larva dari $T$. solium sebagai antigen $C$. cellulosae dengan suspensi $10 \%$ (crude antigen $C$. cellulosae). Kemudian antigen $C$. cellulosae diukur kadar proteinnya dan didapatkan hasil sebesar $876 \mu \mathrm{g} / \mathrm{ml}$, serta dilakukan optimalisasi antigen, konjugat dan sampel serum babi dengan hasil masing-masing yaitu $10 \mu \mathrm{g} /$ well, 1:2000, dan 1:50, yang bertujuan untuk mencari konsentrasi optimal dari antigen, pengenceran optimal sampel serum maupun pengenceran konjugat yang digunakan untuk penelitian (Swacita et al., 2015a).

Prosedur pemeriksaan serum babi, yaitu mula-mula antigen Cysticercus cellulosae masing-masing $100 \mu \mathrm{L} /$ well dicoating dalam mikroplat (kadar protein antigen $876 \mu \mathrm{g} / \mathrm{ml}$, dijadikan $100 \mu \mathrm{g} / \mathrm{ml}$ dengan cara mencampur $1 \mathrm{ml}$ antigen dengan 7,76 $\mathrm{ml}$ coating media, mikroplat diinkubasikan pada suhu $4^{\circ} \mathrm{C}$ semalam, kemudian dicuci 2-3 kali dengan PBS Tween (500 ml PBS + $150 \mu \mathrm{L}$ Tween) masing-masing $200 \mu \mathrm{L} /$ well. Selanjutnya ditambahkan skim milk 5\% (1 g skim milk + $20 \mathrm{ml}$ PBS-T) masing-masing $100 \mu \mathrm{L} /$ well, kemudian diinkubasikan pada suhu $37^{\circ} \mathrm{C}$ selama 30 menit. Skim milk dibuang dari mikroplat tanpa dicuci dengan PBS-T, kemudian ditambahkan serum babi yang diuji dengan pengenceran 1:50 (10 $\mu \mathrm{L}$ serum babi + $490 \mu \mathrm{L}$ PBS-T) masing-masing $100 \mu \mathrm{L} /$ well, selanjutnya diinkubasi pada suhu $37^{\circ} \mathrm{C}$ selama 60 menit. Mikroplat kembali dicuci sebanyak 2-3 kali PBS-T, kemudian ditambahkan konjugat anti swine IgG HRP $(1: 2000=10 \mu$ Lkonjugat $+10 \mathrm{ml}$ PBS-T $)$ masing-masing $100 \mu \mathrm{L} /$ well, selanjutnya diinkubasi pada suhu $37^{\circ} \mathrm{C}$ selama 30 menit. Mikroplat dicuci kembali 2-3 kali dengan PBS-T, kemudian ditambahkan substrat TMB masing-masing $100 \mu \mathrm{L} /$ well $(1: 1=2,5 \mathrm{ml}$ solution $\mathrm{A}+2,5 \mathrm{ml}$ solution $\mathrm{B})$, selanjutnya dilihat reaksi warna yang terjadi, warna yang sama dengan kontrol positif diduga positif. Mikroplat ditambahan stop solution (stopper) masingmasing $100 \mu \mathrm{L} /$ well $(1: 4=1 \mathrm{ml}$ asam sulfat $+4 \mathrm{ml}$ aquades), kemudian dibaca OD-nya pada $450 \mathrm{~nm}$ pada multiscan spectrophotometer. Plat mikro well A1 dan B1 untuk kontrol negatif, sedangkan well C3 dan D4 untuk kontrol positif.

Data optical density (OD) dari kontrol negatif (KN/serum negatif) dan kontrol positif (KP), dicari rataannya, kemudian dihitung ratio OD sampel (S) terhadap rataan $\mathrm{KP}(\mathrm{P})$ menurut rumus :

Ratio $\mathrm{S} / \mathrm{P}=\frac{\text { Rataan } \mathrm{OD}_{\text {sampel }}-\text { Rataan } \mathrm{OD}_{\mathrm{KN}}}{\text { Rataan } \mathrm{OD}_{\mathrm{KP}}-\text { Rataan } \mathrm{OD}_{\mathrm{KN}}}$

Sampel serum dengan ratio $\mathrm{S} / \mathrm{P}<0,7$ adalah negatif (antibodi spesifik terhadap $C$. cellulosae tidak terdeteksi). Sampel serum dengan rasio $\mathrm{S} / \mathrm{P} \geq 0,7$ menunjukkan hasil positif (antibodi spesifik terhadap $C$. cellulosae terdeteksi) (Swacita et al., 2015b).

Seroprevalensi $=$

$\frac{\text { Jumlah Serum Positif }}{\text { Jumlah Sampel }} \times 100 \%$

Pengamatan dan analisis data dilakukan di Laboratorium Balai Besar Veterniner (BBVet) Denpasar dan Laboratorium Virologi Fakultas Kedokteran Hewan Universitas Udayana pada Agustus 2015.

\section{HASIL DAN PEMBAHASAN}

Dari penelitian yang diuji menggunakan uji ELISA terhadap sampel serum babi yang berasal dari wilayah Wamena, Papua ditemukan seroprevalensi sistiserkosis sebesar 39,64\% (44/111) babi yang terindikasi positif terinfeksi Cysticercus cellulosae dan 60,36\% (67/111) terindikasi negatif. Sampel serum 
yang positif terinfeksi Cysticercus cellulosae juga bisa dikarenakan adanya reaksi silang. Penyebab terjadinya reaksi silang antar antigen di atas disebabkan oleh banyaknya kesamaan komponen antigen dari sistiserkus tersebut yang ditangkap oleh antibodi pendeteksi (Sciuto et al., 2007).

Reaksi silang yang terjadi sangat berpotensi untuk menganggu akurasi uji apabila digunakan pada populasi babi yang dipelihara di wilayah endemis Taenia sp selain Taenia solium. Sebagai contoh, Kabupaten Flores Timur, NTT merupakan wilayah endemis sistiserkosis dengan agennya adalah Cysticercus tenuicollis (Saleh, 2010). Bali merupakan daerah endemis sistiserkosis dengan agen penyebabnya tidak hanya Cysticercus cellulosae, melainkan ditemukan juga Cysticercus bovis (Dharmwan et al., 2016; 2020). Metacestoda dari Taenia asiatica pernah ditemukan menjadi agen penyebab sistiserkosis di Pulau Samosir, Sumatera Utara (Ito et al. 2008). Permasalahan reaksi silang yang mungkin terjadi dalam kondisi di atas dapat diatasi dengan melakukan pemeriksaan serologis dan morfologis.

Tabel 1. Seroprevalensi C. cellulosae pada babi dari Wilayah Wamena, Papua

\begin{tabular}{lcccc}
\hline Sampel Serum & \multicolumn{2}{l}{ Interpretasi Uji ELISA } & \multicolumn{2}{c}{ Seroprevalensi } \\
\cline { 2 - 4 } dari Wilayah & Positif & Negatif & Total & \\
\cline { 2 - 4 } Wamena,Papua & 44 & 67 & 111 & $39,46 \%$ \\
\hline
\end{tabular}

Sampel serum yang diperiksa sebanyak 111 sampel ini adalah sampel serum yang dikirim dari Wilayah Wamena, Papua, yang mana sampel ini adalah kumpulan dari beberapa serum babi yang ada di distrik Wamena. Berdasarkan hasil penelitian ini dapat dikatakan bahwa di daerah Wamena, Papua masih ditemukan kasus $C$. cellulosae.

Berdasarkan data pada Tabel seroprevalensi sistiserkosis di daerah Wamena, Papua termasuk dalam kategori daerah endemik. Kategori endemik ini diambil berdasarkan persentase kasus sistiserkosis yang ditemukan lebih dari 10\%. Pengkatagorian ini sesuai dari pernyataan Garcia et al. (2003) yang menyatakan bahwa suatu daerah dikatakan endemis sistiserkosis bila memiliki prevalensi penyakit ini lebih dari $10 \%$. Namun, Noble (1989) menyatakan bahwa prevalensi sistiserkosis pada daerah nonendemis biasanya kurang dari $1-2 \%$.

Tingginya seroprevalensi sistiserkosis babi dari wilayah Wamena, Papua ini diduga karena pemeliharaan babi yang masih dipelihara secara bebas atau diumbar dan juga dikarenakan masyarakat yang masih belum memiliki toilet atau jamban.
Menurut Purba et al, (2003), toilet dengan kejadian sistiserkosis memiliki hubungan dengan nilai odds ratio sebesar 6,2. Nilai ini bermakna bahwa dengan memiliki toilet maka dapat menurunkan jumlah kasus infeksi sistiserkosis sebesar 6,2 kali daripada yang tidak memiliki toilet. Flores et al, (2001) melaporkan bahwa kepemilikan toilet dan kesadaran masyarakat untuk defekasi tidak di sembarang tempat berhasil menurunkan kasus sistiserkosis di Meksiko hingga 50\%. Fungsi dari toilet dalam menekan penyakit ini adalah mencegah pencemaran dari feses manusia yang mengandung telur infektif Taenia solium. Keberadaan telur infektif Taenia solium di lingkungan harus dicegah karena telur ini mampu bertahan lama di lingkungan. Menurut Soulsby (1986), telur infektif dari Taenia solium mampu bertahan hidup selama 71 hari dalam feses basah, 16 hari dalam sampah, 8 minggu pada daerah yang kering, dan 14,5 minggu dalam lahan penggembalaan.

Selain faktor sanitasi lingkungan tingginya seroprevalensi sistiserkosis di wilayah Wamena, Papua juga diduga kebiasaan masyarakat lokal yang masih kurang peduli dengan higiene personal. 
Kasus taeniasis dan sistiserkosis sangat berkaitan erat dengan higiene personal, pemeriksaan daging babi, dan cara mengolah daging babi sebelum dikonsumsi. Higiene personal berperan untuk mencegah masuknya telur Taenia solium infektif ke dalam tubuh manusia. Wujud dari higiene personal antara lain yaitu mencuci tangan sebelum makan, mandi, memakai alas kaki dan memasak air minum. Menurut Purba et al, (2003), mencuci tangan sebelum makan memiliki korelasi terhadap kejadian sistiserkosis. Nilai odd ratio dari dua hal di atas sebesar 4,9 nilai ini bermakna bahwa seseorang yang tidak mencuci tangan sebelum makan memiliki risiko 4,9 kali lebih tinggi terjangkit sistiserkosis. Memasak air sebelum dikonsumsi merupakan salah satu tindakan higiene pangan yang bertujuan untuk mematikan telur Taenia solium infektif dalam air. Seseorang memiliki risiko menderita sistiserkosis lebih besar bila mengkonsumsi air yang tidak dimasak dibandingkan dengan air yang telah dimasak.

Penularan Cysticercus cellulosae pada manusia sangat berhubungan erat dengan pola pengolahan daging babi sebelum dikonsumsi. Masyarakat yang mengkonsumsi daging babi bakar dan mentah memiliki risiko lebih besar terinfeksi taeniasis. Hal ini disebabkan oleh Cysticercus cellulosae dalam daging babi akan mati dalam pemanasan sempurna yaitu diatas suhu $60^{\circ} \mathrm{C}$ (Soejoedono, 2004). Upacara Bakar Batu yang dilakukan oleh masyarakat setempat berisiko sebagai cara masuk sistiserkus kepada manusia bila tidak dilakukan dengan pemanasan dan lama pembakaran yang tepat.

Faktor-faktor diatas merupakan penyebab adanya seroprevalensi infeksi $C$. cellulosae pada babi dari wilayah Wamena, Papua. Apabila hal itu terus berlanjut maka akan sulit untuk memutus siklus penyakit sistiserkosis pada babi maupun manusia, karena bukan hanya babi yang dipelihara dengan baik melainkan kebersihan dan kesehatan manusia juga dapat mempengaruhi terputusnya siklus penyakit ini.

Untuk mengendalikan kasus sisitiserkosis pada babi di wilayah Wamena, Papua maka perlu tetap dilakukan pencegahan yang lebih baik dengan cara tetap melakukan monitoring secara berkala dan bila perlu melakukan vaksinasi pada babi serta pengobatan cepat apabila ditemukan penderita taeniasis. Selain itu perlu juga diberikan edukasi atau penyuluhan kepada masyarakat berupa pemberian pendidikan kesehatan terhadap penyakit sistiserkosis dan taeniasis, yaitu dengan mengonsumsi daging yang benarbenar matang, peningkatan higiene perseorangan di lingkungan dengan cara tidak membuang air besar di sembarang tempat, serta perbaikan sistem peternakan, terutama bagi peternak yang masih memelihara babi secara tradisional sehingga dapat memutus siklus hidup cacing pita di dearha tersebut.

\section{SIMPULAN}

\section{Simpulan}

Berdasarkan hasil penelitian maka dapat disimpulkan seroprevalensi sistiserkosis pada babi sampel di wilayah Wamena, Papua sebesar 39,64\%.

\section{Saran}

Dari hasil penelitian ini disarankan beberapa hal terkait dengan pengendalian sistiserkosis pada babi dan manusia di wilayah Wamena, Papua yaitu; Perbaikan sistem pemeliharaan babi, yaitu dengan cara mengandangkan babi supaya tidak memakan feses manusia serta pemberian obat cacing kepada babi dan manusia. Usaha yang dapat dilakukan untuk mengurangi kasus sistiserkosis-taeniasis baik pada babi maupun manusia di wilayah Wamena, Papua, adalah memperbaiki sanitasi lingkungan yaitu dengan meningkatkan jumlah toilet dan kesadaran masyarakat setempat untuk tidak defekasi di sembarang tempat, serta tidak mengonsumsi daging babi yang tidal atau setengah matang. Perlu dilakukan 
penelitian lebih lanjut dengan besaran sampel yang lebih representatif agar diketahui jumlah prediksi kasus yang lebih valid guna merancang program pencegahan dan penanggulangan penyakit Taeniasis dan Sistiserkosis di wilayah ini.

\section{DAFTAR PUSTAKA}

Agustina KK, Wirata IW, Dharmayudha AAGO, Kardena IM, Dharmawan NS. 2016. Increasing farmer income by improved pig management systems. Buletin Veteriner Udayana. 8(2): 122127.

Agustina KK, Swacita IBN, Oka IBM, Dwinata IM, Traub RJ, Cargill C, Damriyasa IM. 2017. Reducing zoonotic and internal parasite burdens in pigs using a pig confinement system. Vet. World. 10(11): 1347-1352

Ardana IB, Putra DKH. 2008. Ternak babi manajemen reproduksi, produksi dan penyakit. Udayana University Press. Denpasar.

Assa IF, Satrija DW, Lukman NS, Dharmawan, dan P Dorny. 2012. Faktor risiko babi yang diumbar dan pakan mentah mempertinggi prevalensi sistiserkosis. J. Vet. 13(4): 345-352.

NS Dharmawan, Dwinata IM, Swastika K, Damriyasa IM, Oka IBM, Agustina KK. 2016. Biological studies of Taenia saginata metacestoda development in bali cattle. Buletin Veteriner Udayana. 8(1): 59-64.

Dharmawan NS, Damriyasa IM, Mahardika IG, Swastika K, Hartiningsih LP, Agustina KK. 2020. A seroepidemiological study of bovine cysticercosis in Bali and Nusa Tenggara, Indonesia. Vet. World. 13(2): 284-289.

Dinas Kesehatan Kabupaten Jayawijaya. 2006. Laporan kasus penyakit taeniasis, sistiserkosis dan neurosistiserkosis di Kabupaten Jayawijaya Tahun 2004 2005. Wamena.

Flores SV, Rodea GB, Flisser A, Schantz PM. 2001. Hygiene and restraint of pigs is associated with absence of Taenia solium cysticercosis in a rural community of Mexico. Salud Pública de México. 43: 574-576.

Garcia HH, Gonzalez EA, Evans WA, Gilman RH. 2003. Taenia solium cysticercosis. The Lancet. 361: 547556.

Ito A, Sato Y, Nakao M, Nakaya K, Okamoto M, Wandra T, Kandun IN, Anantaphruti MT, Waikagul J, Tiaoying L, Qiu D. 2008. Molecular and immunological diagnosis of taeniasis and cysticercosis in Asia and the Pacific. Southeast Asian J. Trop. Med. Public. Health. 39: 37-49.

Maitindom FD. 2008. Studi kejadian sistiserkosis pada babi yang dijual di Pasar Jibaman Kabupaten Jayawijaya Papua Tesis. Bogor: Program Pascasarjana, Institut Pertanian Bogor.

Margono SS, Ito A, Sato MO, Okamoto M, Subahar R, Yamasaki H, Hamid A, Wandra T, Purba WH, Nakaya K, Ito M, Craig PS, Suroso T. 2003. Taenia solium taeniasis/cysticercosis in Papua, Indonesia in 2001: detection of human worm carriers. J. Helminthol. 77: 3942.

Noble ER, Noble GA, Schad GA, MacInnes AJ. 1989. Parasitology: The biology of animal parasites. USA: Lea $\&$ Febiger

Purba WH, Miko TYW, Ito A, Widarso HS, Hamid A, Subahar R, Margono SS. 2003. Faktor-faktor yang berhubungan dengan kejadian sistiserkosis pada penduduk Kecamatan Wamena, Kabupaten Jayawijaya, Propinsi Papua tahun 2002. Makara Kesehatan. 7: 5665.

Saleh USA, Sanjaya AW, Satrija F. 2010. Faktor risiko kejadian sistiserkosis pada babi di Kabupaten Flores Timur Nusa Tenggara Timur. Tesis. Bogor: Program Pascasarjana, Institut Pertanian Bogor.

Sciutto E, Chavarria A, Fragoso G, Fleury A, Larralde C. 2007. The immune response in Taenia solium 
cysticercosis: protection and injury. Parasite Immunol. 29: 621-636.

Soulsby EJL. 1986. Helminths, Arthropods, and Protozoa of Domestic Animals. London: Balliere Tindall.

Swacita IBN, Damriyasa IM, Dharmawan NS, Astawa NM, Apsari IAP, Tenaya IWM. 2015a. Respons imun mencit yang diimunisasi dengan Cysticercus cellulosae. J. Vet. 16(2): 181-186.

Swacita IBN, Agustina KK, Polos IW, Fitriani S, Natalia. 2015b. Survei seroprevalensi Taenia solium sistiserkosis di Kabupaten Mimika, Papua. Buletin Veteriner Udayana. 7(2): 172-178.

Wandra T, Margono SS, Gafar MS, Saragih JM, Sutisna P, Sudewi AAR, Depari AA, Yulfi H, Darlan DM, Okamoto M, Sato MO, Sako Y, Nakao M, Nakaya K, Craig PS, Ito A. 2007. Current situation of taeniasis and cysticercosis in Indonesia. Trop. Med. Health. 35: 323328. 